\title{
光干渉断層計（OCT）を用いたう蝕と龟裂の診断の可能性と限界
}

\author{
島田康 史 ${ }^{1)}$ 田上 順 次 ${ }^{1)}$ 角 保 徳 ${ }^{2)}$ \\ 1) 東京医科歯科大学大学院医歯学総合研究科う蝕制御学分野 \\ 2) 国立長寿医療研究センター歯科口腔先進医療開発センター歯科口胿先端診療開発部 \\ （受付： 2014 年 10 月 18 日，受理 : 2014 年 11 月 25 日）
}

\section{Potential and Limitations of OCT for Assessing Dental Caries and Tooth Crack}

\author{
Yasushi SHIMADA $^{1)}$, Junji TAGAMI ${ }^{1)}$ and Yasunori SUMI ${ }^{2)}$ \\ 1) Cariology and Operative Dentistry, Tokyo Medical and Dental University \\ 2) Department of Advanced Dental Research Center of Advanced Medicine for Dental and Oral Diseases, \\ National Center for Geriatrics and Gerontology
}

(Received: October 18, 2014, Accepted for Publication: November 25, 2014)

\begin{abstract}
Optical coherence tomography (OCT) constructs images through the wave interference that occurs when backscattered light from a sample is coupled with a reference light. OCT visualizes differences in the tissue's optical properties, which includes the effects of both optical absorption and scattering. In particular, swept-source OCT (SS-OCT) can construct images through the ultrahigh-speed scanning of the time-encoded wavelength of a near-infrared laser. The purpose of this study was to apply this technology in the practice of dentistry for imaging teeth and composite restorations, which may facilitate the clinical diagnosis of caries and tooth cracks, as well as the evaluation of existing restorations in the future.

The SS-OCT images obtained by intraoral scanning that involved sound or slightly demineralized enamel up to the deep dentin caries were examined and compared with those of the radiographs. In SS-OCT, sound enamel is almost transparent at the SS-OCT wavelength range or upper near-infrared region around $1,300 \mathrm{~nm}$. In caries lesions, the signal generally increases and the demineralized region appears brighter on the grayscale SS-OCT images, because of the formation of numerous submicron-size defects resulting from demineralization in carious lesions. If the caries penetrates into dentin, the penetration depth of the bright zone observed in SS-OCT extends beyond the DEJ level. In some cases, lateral expansion of the caries lesion creates micro gaps along the DEJ, where strong reflection occurs.

Cracked teeth have been a diagnostic challenge because of the difficulty in locating crack lines on incomplete tooth fractures. Since a crack has an unpredictable prognosis, including extraction, accurate diagnosis regarding the size and localization of the crack is required to determine the most appropriate treatment technique. We examined SS-OCT as a diagnostic tool for tooth cracks, and this methodology proved capable of providing clear imaging of tooth cracks, including information on penetration depth.

Since OCT is an optical imaging modality, its principal disadvantage is that the light attenuation from scattering by tissue limits the image penetration depth. Also, images obtained in OCT are significantly influenced by the optical properties of biological structures, e.g. the refractive index, which determines light refraction and light speed. However, OCT is a promising imaging technology in dentistry, because it performs real-time cross-sectional imaging of the tissue microstructure without the need for radiation dosing.
\end{abstract}

(J. Jpn. Soc. Laser Dent. $25: 159 \sim$ 164, 2014 Reprint requests to Dr. SHIMADA)

Key words $=$ Optical coherence tomography, SS-OCT, Diagnosis, Caries, Tooth crack

キーワード=光干渉断層計, SS-OCT, 診断, う蝕, 歯の亀裂

干 113-8549 東京都文京区湯島 1-5-45 TEL 03-5803-5483 FAX 03-5803-0195

1-5-45 Yushima, Bunkyo-ku, Tokyo 113-8549, Japan. TEL + 81-3-5803-5483 FAX + 81-3-5803-0195 


\section{OCT の原理}

光干渉断層計 (Optical Coherence Tomography, OCT) は, 光の干渉作用を用いて組織内部の断層画像を得る技術 である。1990 年に世界で初めて丹野直弘 (元山形大学教授) から出願特許が出され，世界的には 1991 年に Huang, Fujimoto らによって, 連続スキャンによる画像化が開発され た ${ }^{1,2)}$ 。現在では眼科の眼底疾患の検查をはじめ, 皮膚科, 循環器科など，多くの臨床医学分野に用いられている。

OCT は，まず生体に光を照射して，生体内部から返っ てくる後方散乱光に, 別光路の光を合波させ, その干渉シ グナルを分析して画像を構築する（図 1)。組織に光を浸 透させて干渉シグナルを得るため, 光源の位相をそろえる 必要があり, 生体に安全な近赤外レーザーが用いられてい る。初期の OCT は, 光の干渉を実空間（時間領域）でお こなうタイムドメイン OCT であり, 干渉情報が 1 点しか 得られないため, 深さ方向の情報を捉えるためには光路長 を機械的に変化させて走査する必要があった。その後, 強 度の異なる散乱光のシグナルを, 成分ごとに計算し, フー リエ空間（周波数領域または波長領域）で行う技術（フー リエドメイン OCT）が開発され，1回のスキャンで深さ 方向の情報がすべて取得できるようになり，画像解像度は 飛躍的に向上した。フーリエドメイン OCT には, 波長固 定光源と分光器を用いてフーリエ空間で検出するスペクト ラルドメイン OCT と, 光源の波長を高速で変化させる波 長走查型 OCT (SS-OCT) とがある。歯科では, 光源自 体の波長領域を時間的に変化させ，掃引して干渉シグナル を得るSS-OCT が, 大きな検出器を必要とせずに装置を 小型化できること, 画像の解像度と深度が優れているこ と, 処理速度が速くモーションアーチファクトに強いこと などから, 臨床に打ける実用性が高いと認識されている $\left(\right.$ 図 1) ${ }^{3,4)}$ 。

OCT は光を用いる画像機器であることから, 光を通さ ない物体の観察には適さない。しかしながら, 画像解像度 は光学顕微鏡レベルであり, CT や超音波断層画像など, 他の生体断層画像撮影装置よりも高い。また放射線の被曝 リスクがなく, 小児や妊婦にも安全に使用できるため, 臨 床でのメリットは大きい。

\section{OCT の特性}

歯科領域で用いられる OCT には, 光源として主に波長 1,300nm 付近のレーザーが用いられ，これは，生きた組織 ではへモグロビンなどのへムに由来する光吸収スペクトル が700nm 以下にあること, また, 1,400nm 以上の波長域 では水への吸収が増大するため, $700 〜 1,400 \mathrm{~nm}$ の近赤外 波長域が生体にて高い透過性を示すことを利用している。 さらにエナメル質の光透過性は $1,300 \mathrm{~nm}$ 付近で高いこと

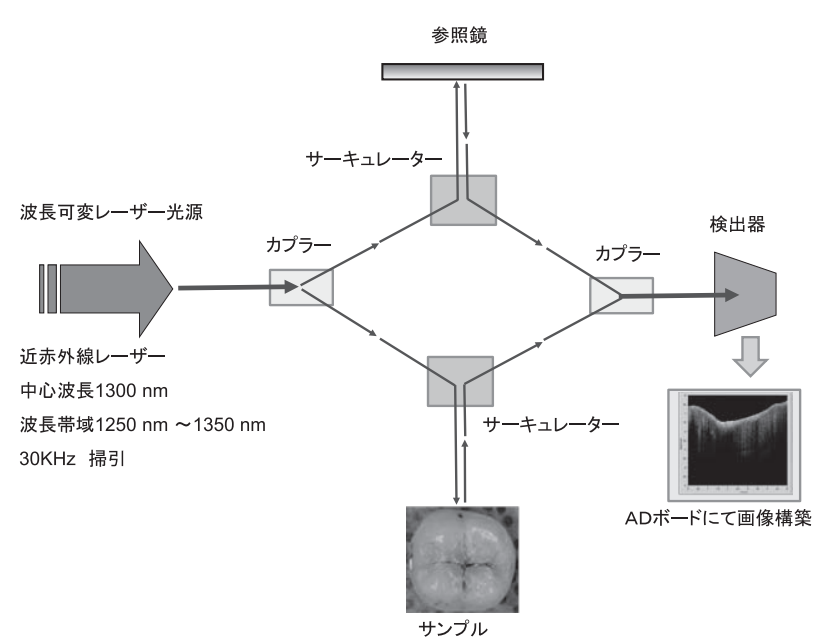

図 1 波長走査型光干渉断層計 (SS-OCT) の原理 光源から一定の波長域で時間的に変化する波長を有する近 赤外レーザーがサンプルに照射され，参照鏡側の光路の レーザーと合波させ，干渉シグナルを得る。それぞれの波 長成分の変化が時間的にコード化されており, 深さ方向の 変化となって画像が構築される。

が知られており，実際に歯の OCT 観察を行うと，エナメ ル質のほぼ全層を画像表示することができる。

OCT の画像解像度と画像深度は, 文献的に共焦点レー ザー顕微鏡と超音波断層画像診断との中間に位置すると理 解されている $(\text { 図 2 })^{2)}$ 。画像解像度は, 水平方向は主に レーザー光源のスポットサイズに依存しており，20～30 $\mu \mathrm{m}$ になる。また垂直方向は光の干渉作用に依存してお り, $10 \sim 15 \mu \mathrm{m}$ と考えられている。

OCT は, 生体に光を照射し, 組織内部からの後方散乱 光を利用して干渉シグナルを作製し, 画像を構築する。組 織内部からの反射は, 屈折率の異なった媒体の界面で生じ る現象である。したがって OCT は, 生体内部の光学的性 質の変化を捉えて画像を構築するということができる。異 なる組織の境界や病変部では屈折率が変化するため, そこ で光が散乱し, OCT 画像にて識別することができるので ある。

\section{う蝕の診断}

\section{1）健全部の SS-OCT 画像}

健全歯を SS-OCT 観察すると, 空気とエナメル質の屈 折率の相違から, 歯表面で光が反射するために輝度が上昇 し, 白くみえる。また, エナメル質を透過して象牙質に達 すると, 屈折率の相違からエナメル象牙境 (EDJ) が表示 され，2つの組織を区別することができる(図 3 左)。平 滑面から歯の内部を SS-OCT 観察すると, 比較的容易に 鮮明な画像が得られるが，咬合面のような凹凸に富んだ歯 面では, 咬頭の傾斜角度によって光の反射が強くなり, 深 部への光の到達が妨げられ, 画像深度が低下しみえにくく 


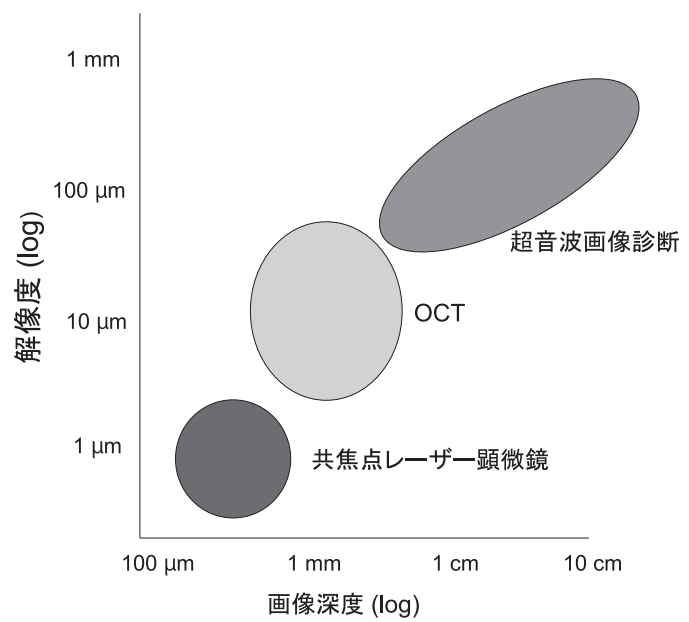

図 2 画像の解像度と深度の比較

OCT の画像解像度と深度を他の画像機器と比較した場合, 超音波画像診断と共焦点レーザー顕微鏡の中間に位置すると いわれている。超音波画像診断は画像深度に優れている。共 焦点レーザー顕微鏡は優れた画像解像度を示すが, 画像深度 は低い。OCT の画像深度は観察対象物の光透過性に強く依 存し, 数 $\mathrm{mm}$ であり, また解像度は約 $10 \mu \mathrm{m}$ である（文献 2)より引用)。

なることがある。この様な場合, 様々な方向から角度を変 えて観察を行うなど，適切な画像を得るための工夫が求め られる。

\section{2）う蝕の SS-OCT 画像}

SS-OCT を用いてう蝕を観察すると, 病変部の輝度が上 昇し，周囲の健全部と比較すると白く表示される（図 3 右)。X 線写真ではう蝕の X 線透過性が高まり, 健全部よ りも黒く映るが，SS-OCTでは逆に白くなることが多いた め, 注意しなければならない。これは，脱灰による微小な 欠陌が無数に形成され，そこに水や組織液が侵入し，屈折 率の変化が生じるためと理解されている。東京医科歯科大 学う蝕制御学分野において行われた一連の研究の中で, エ ナメル質ならびに象牙質の脱灰の状態と, 屈折率の変化を 計測した結果，歯のミネラル密度と屈折率の変化に相関が みられることを報告し, SS-OCT 画像の輝度の変化によっ てう蝕の診断が行えることを理論的に証明した ${ }^{5)}$ 。また, 脱灰によって近赤外レーザーの減衰係数が変化し, 画像深 度が低下することも判明 ${ }^{6)}$, う蝕診断への応用が期待さ れている。

\section{3）隣接面う蝕の診断}

プロトタイプの SS-OCT がパナソニクヘルスケア株式 会社より開発され（図 4), 臨床現場で使用する機会が得 られ, 東京医科歯科大学歯学部附属病院に来院した患者か ら甶歯隣接面う蝕の診断を試みた4)。まず視診を行い，う 窩の開口部が直視できない症例を抽出し, 次に, SS-OCT を用いて咬合面側から画像を撮影し, 通常のデンタルX 線写真を用いた診断と対比した。その後，う蝕の治療を行

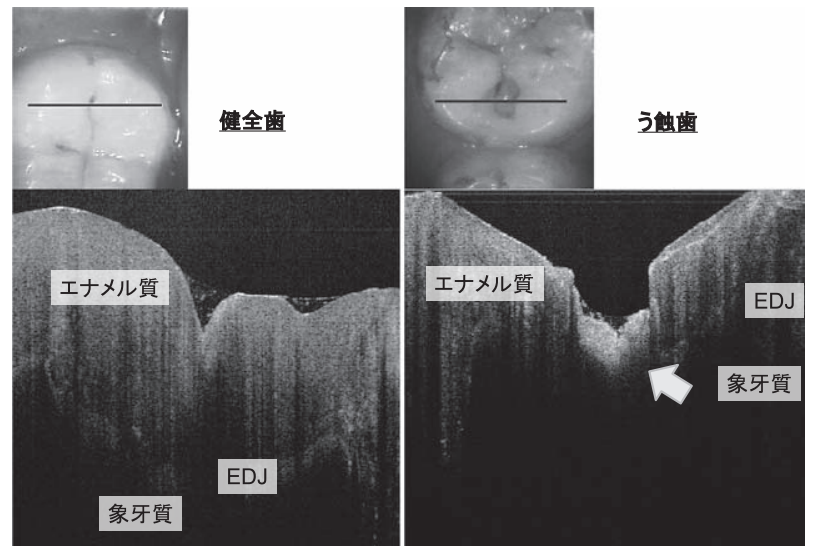

図 3 咬合面小窩の SS-OCT 画像（上段赤線の断層画像） 左：健全歯, 右：う蝕歯

健全歯では，エナメル質，象牙質，エナメル象牙境（EDJ） が表示され，明瞭に区別することができる。う蝕では輝度 が上昇し，白く画像表示されている (矢印)。

い，う蝕検知液をガイドとした検査とう蝕除去後の窩洞の 深さを基準とし，診断精度を評価した。

実質欠損を伴わない比較的初期段階のう蝕が隣接面に存 在する場合, SS-OCT 画像は白くなり, う蝕病変部として の特徵的な画像を得ることができる（図 5)。これは脱灰 による変化であり，X 線写真では検出不可能な，ごく初期 のエナメル質脱灰でも同様の画像が得られる。この様な場 合，臨床では窩洞形成を行わずにフッ化物を応用するな ど，再石灰化治療を選択することも考えられる。したがっ て, 治療としての切削介入を行うには, 事前に脱灰の範囲 と深さを SS-OCT 画像にて鑑別し，慎重に判断する必要 がある。

図 6 に，隣接面の象牙質う蝕を示す。本症例では，視診 にて歯質の着色がみられても, デンタルX線写真による 変化はわずかであった。このように，X線写真では，実際 にう蝕があっても検知できないことがあり，文献的にも感 度が低いことが理解されている。一方，SS-OCT ではう蝕 の歯頂側の窩縁部が表示され，それが EDJに沿って深く 浸透している様子を観察することができる。

隣接面に実質欠損のみられるう蝕では, 窩縁部歯質での 強い輝度の上昇がみられる一方で, 久損部においてシグナ ルが脱落していることがある（図 7)。う蝕窩縁部とう蝕象 牙質のシグナルの上昇は強い変化であり，エナメル質脱灰 病変と区別することができる。このようにして SS-OCT を 用いれば，隣接面のう蝕を正確に診断することができる。

その一方で, SS-OCT の光透過性には限界があるため, 深く進行したう蝕において, 歯髄までの到達度を診断する ことは困難である。図 8 では, SS-OCT では隣接面に輝度 の上昇がみられ，う蝕の存在を診断することはできたが， う蝕の深さを正確に判断することはできなかった。歯髄処 


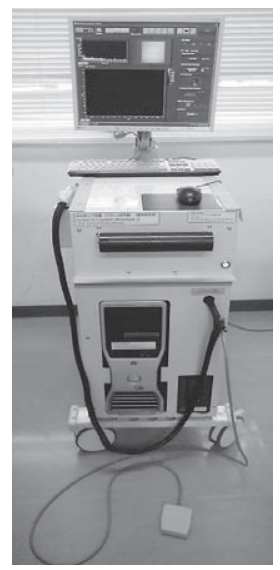

\begin{tabular}{|l|c|}
\hline \multicolumn{2}{|c|}{ 歯科用SS-OCT (パナソニックヘルスケア) } \\
\hline 中心波長、波長域 & $\begin{array}{c}1330 \mathrm{~nm} \\
1280-1380 \mathrm{~nm}\end{array}$ \\
\hline 垂直画像解像度 & $12.0 \mu \mathrm{m}$ (空気中) \\
\hline 水平画像解像度 & $20.0 \mu \mathrm{m}$ (空気中) \\
\hline 計測速度 & $30,000 \mathrm{line} / \mathrm{sec}$ \\
\hline 3D 画像構築時間 & $4 \mathrm{sec}$ \\
\hline 画像深さ & $<7.0 \mathrm{~mm}$ \\
\hline 画像幅 & $<7.0 \mathrm{~mm}$ \\
\hline
\end{tabular}

図 4 パナソニックヘルスケアにて開発されたSS-OCT（プ ロトタイプ)

口腔内で画像を取得できるプローブが装着されており，前歯部 のみならず，且歯隣接面のう蝕診断などに用いることができる。

置の必要性を診断するには，X 線写真によってう蝕の全体 像を把握し，う蝕の深さと歯䯣との位置関係を検査する必 要があると思われる。

\section{歯冠部亀裂の診断}

歯の亀裂は早期発見が困難な疾患であり，冷水痛や咬合 痛などの強い症状によってはじめて診断されることが多 い。歯髄症状を伴う場合，すでに亀裂は進行しており，抜 髄や抜歯など侵襲的な治療が必要なこともある。しかしな がら，歯の亀裂は幅十数ミクロンといった報告があり，複 雑な走行を示すことから，視診や X 線写真を用いて早期 に検出できる可能性は極めて低い。近年の臨床では, 歯に 光をあてて亀裂の陰影を観察する透照診が用いられ，比較 的良好な結果を収めているが，その適用は光をあてながら 視診が行える歯面に限られること，また亀裂の深さを正確 に診断できないことなどが欠点として挙げられる。深さ方 向の情報の欠如は, 治療方針を決める上で大きな制約と なってしまう。

歯の亀裂面では光が反射することから， SS-OCT を用い れば正確な診断が可能であり，有用性が高いと期待されて いる。Imai らはSS-OCTを用い, ヒト抜去歯にみられる 歯の亀裂の診断を，正確に行えることを報告している7

図 9 に，上顎第 2 大臼歯の遠心歯根面にみられた亀裂を 示す。数年前より冷水痛があり, いくつかの歯科医院を受 診したが, 治療が行われず, 経過観察を繰り返していた。 数か月前より冷水痛が強くなり, 当診療科を受診, SSOCT による画像診断を行うことになった。なお，同部位に おける歯周ポケットは $5 \mathrm{~mm}$ 程度であり, 歯周組織への変 化は少なく，通常の手段では診断が困難な状況であった。

患歯の歯頸部において, 遠心側から水平方向に SS-OCT
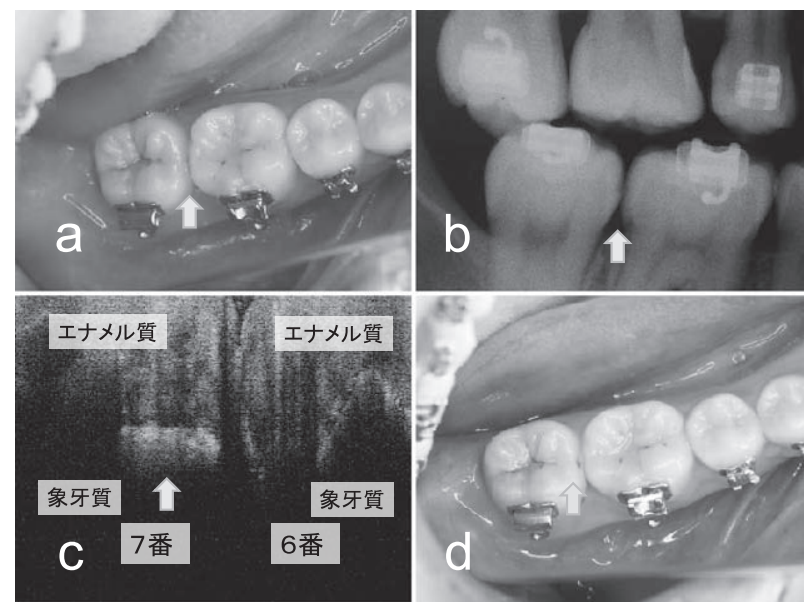

図 5 隣接面う蝕の SS-OCT 画像, 右下第 2 大臼歯エナメル 質う蝕

$\mathrm{a}$ : 術前口腔内写真。視診では, 隣接面にう蝕を疑う変化はみら れない (矢印)。

b : デンタル X 線写真 (バイトウイング法)。7 番の近心なら びに 6 番遠心に，わずかに透過像がみられる（矢印）。

c : SS-OCT 画像。 7 番の接触点下の輝度が上昇し, EDJ ま で侵入していることがわかる（矢印）。しかしながら， 6 番の変化はわずかである。

$\mathrm{d}$ ：う蝕除去, 窩洞形成後の状態。7 番に歯質保存を試み, 必要最小限の窩洞形成をおこなった（矢印）。6 番遠心に う蝕はみられない。

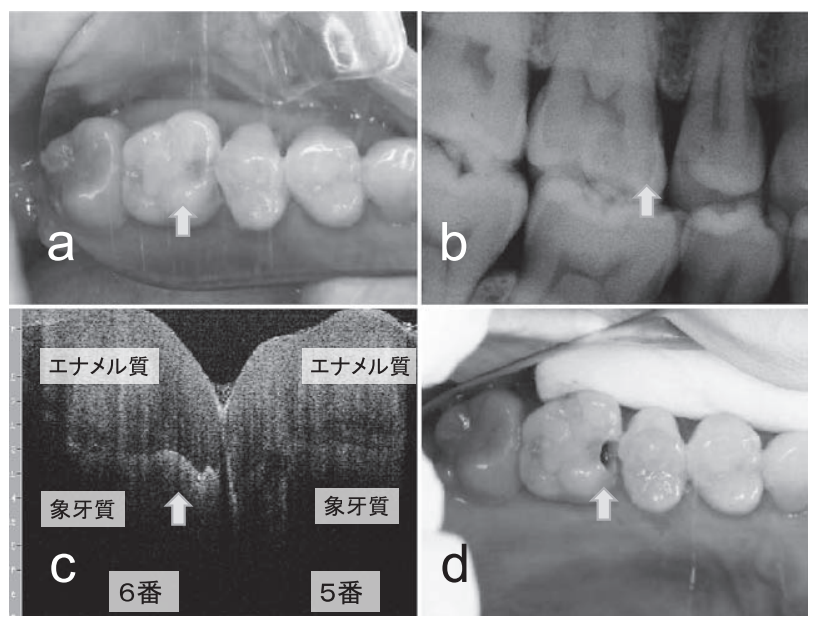

図 6 隣接面う蝕の SS-OCT 画像, 右上第 1 大臼歯象牙質う蝕 $\mathrm{a}$ : 術前口腔内写真。視診では, 6 番近心隣接面に黒変がみら れ，う蝕が疑われる（矢印）。

$\mathrm{b}$ ：デンタル X 線写真 (バイトウイング法)。6 番の近心なら びにその周囲に大きな変化はみられない（矢印）。

$\mathrm{c}$ ：SS-OCT 画像。6 番の接触点下に境界明瞭な輝度の上昇が みられ，EDJに沿って深く侵入している（矢印）。う蝕の 象牙質への侵入と，う窩の形成が疑われる。

$\mathrm{d}$ ：う窩の開放, 窩洞形成途中後の状態。6 番の近心隣接面 は, 中等度以上に進行した象牙質う蝕であることがわか る (矢印)。

を用いてスキャンして観察したところ，象牙質表面から歯 髄方向に, 内部に亀裂が深く侵入している様子が表示され た。チェアーサイドで画像を患者に提示したところ, 必要 


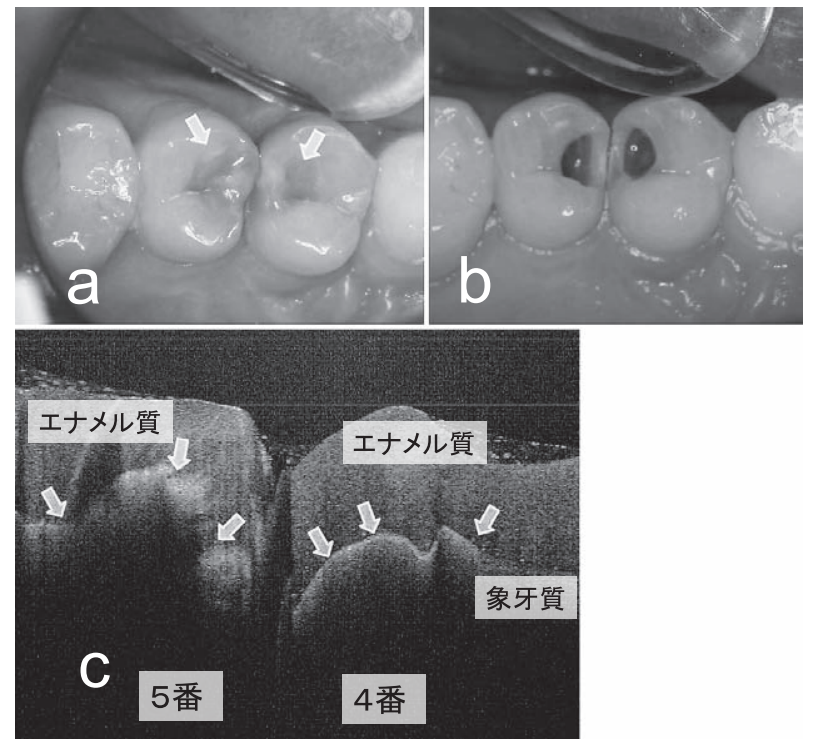

図 7 う窩の形成がみられる隣接面う蝕の SS-OCT 画像, 右 上第 1 , 第 2 小臼歯

$\mathrm{a}$ : 術前口腔内写真。視診にて黒変がみられ, 明らかに隣接 面う蝕が疑われる（矢印）。

b : う窩の開放, 窩洞形成途中。 4 番, 5 番ともにう蝕が進行 し，大きなう窩の形成がみられた。

$\mathrm{c}$ ：術前の SS-OCT 画像。 4 番, 5 番ともにう蝕が拡大し, 咬 合面下に拡大している様子がわかる。4 番ではう窩の壁面 が白線となって拡がっている。5 番では不均一な輝度の上 昇部がみられ，多量の感染歯質の存在が疑われる。

な治療に対する患者の同意も速やかに得られ，歯冠修復治 療を行うことができた。Imai らの実験によると, SS-OCT による亀裂の検出は, 光照射器の青色光を用いた透照診よ りも正確であり，また亀裂の深さを正確に診断できる。ま た術者間での診断の一致率も高いことが示されている7)。し たがって, SS-OCT は亀裂の診断への有用性が極めて高い。

\section{コンポジットレジン修復物の二次う蝕とギャップの診断}

コンポジットレジンはある程度の光を透過することか ら， SS-OCT を用いて窩底部のギャップや二次う蝕を評価 することができる。コンポジットレジンの光透過性は色調 やフィラー形態の影響を受けるため製品によって異なる が，厚さ数 $\mathrm{mm}$ であれば修復物の窩底部の変化を観察す ることができる。

Makishi らは, コンポジットレジン修復の 3D 画像構築 をSS-OCTによって行い，䆟底部のギャップを正確に捉 えることができること采，またBakhsh らは，コンポジッ トレジン修復の窩底部に生じたギャップは光を強く反射す るため，幅 $1 \mu \mathrm{m}$ でも検知できることを報告した ${ }^{9)}$ 。図 10 に，歯䅡部のコンポジットレジン修復にみられたギャップ の SS-OCT 画像を示す。Ishibashi らは臨床でSS-OCT を 使用し、コンポジットレジン修復下のギャップと二次う蝕

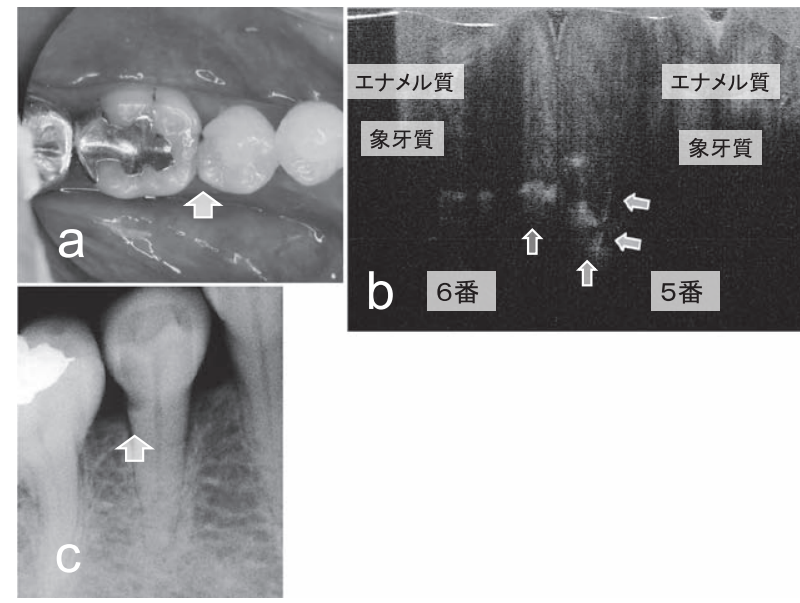

図 8 深い隣接面う蝕により抜髄に至った症例の SS-OCT 画像 $\mathrm{a}$ : 術前口腔内写真から, 右下 5 番にう蝕がみられる (矢印)。

$\mathrm{b}$ : 術前の SS-OCT 画像。5番の接触点下の輝度が上昇し, EDJに沿った拡大が疑われ (矢印), 深いう蝕と思われる。 6 番にも歯質の輝度が上昇しており，う蝕が疑われる。

$\mathrm{c}$ ：デンタル X 線写真 (二等分法)。う蝕は歯髄に近接し, 露 髄していると考えられる (矢印)。
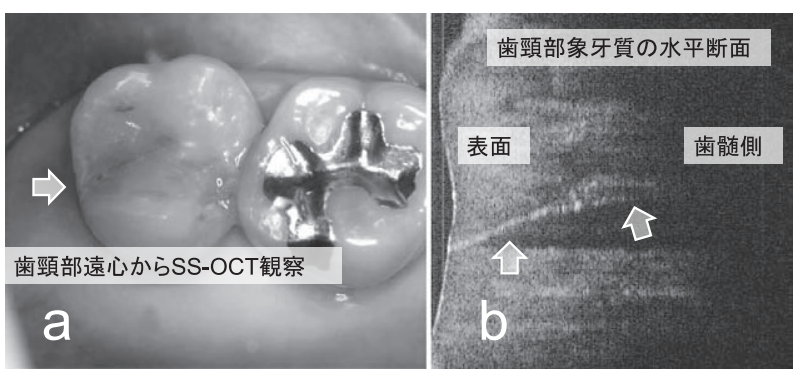

図 9 歯根亀裂（不完全破折）の SS-OCT 画像

$\mathrm{a}$ : 術前口腔内写真。上顎 7 番に強い知覚過敏がみられた。 咬合面からの視診では, 亀裂は不明瞭 (矢印)。

b : SS-OCT 画像。 7 番の歯䅡部の遠心から, 咬合面に対して 平行にスキャンを行い, 歯頚部象牙質の断層画像を撮影 した。咬合面にみえる亀裂が歯頸部の水平断層画像にも みられ, 象牙質から歯髄方向へ深く侵入している様子を 白線として明瞭に観察できる (矢印)。
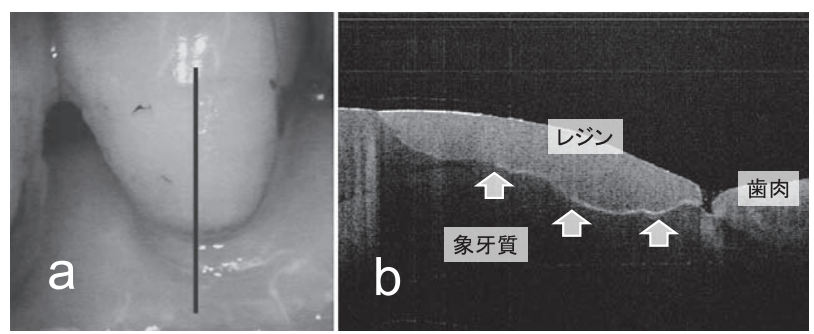

図 10 歯澒部のコンポジットレジン修復の SS-OCT 画像 $\mathrm{a}$ : 口腔内写真。歯澒部にコンポジットレジン修復が行われ ている。赤線に沿って, SS-OCT 画像を取得した。

b : レジン修復物の歯肉側窩縁から, 接着界面が白く画像表示 されており，ギャップが形成され一部剥離している様子が わかる (矢印)。右矢印〜中矢印 : 完全なギャップ, 剥離し ていると思われる。中矢印〜左矢印：不完全なギャップ, 接着界面が劣化しており, 剥離しつつあると思われる。 
を明瞭に観察できることを報告している ${ }^{10)}$ 。今後，コンポ ジットレジン修復の長期予後観察にも利用できると考えら れる。

\section{OCT 画像診断の限界と注意点}

OCT の画像深度は, 組織の光透過性に大きく左右され る。歯科ではエナメル質や象牙質の光透過性を利用して, う蝕や歯の亀裂の診断を行うことができる。しかしなが ら, 光を通さないものは適応外であり, メタルインレーや 全部鋳造冠など, 金属製修復物の内面の二次う蝕をみるこ とはできない。

歯肉などの軟組織は, 光を散乱・吸収しやすいため, 透 過性が低く, 画像深度は約 $2 \mathrm{~mm}$ である。象牙質の光透過 性はエナメル質よりも低いため, う蝕が深い場合, 歯䯣処 置の必要性を判断することは難しく, 他の診断検査法を併 用する必要がある。

またOCT 画像は, 屈折率の影響を強く受ける。屈折率 は光の透過しやすさを相対的に示す数值であり, たとえば 屈折率が 1.5 の場合, 光の透過する速度は $1 / 1.5$ に減速し, 光学的な距離は 1.5 倍になる。ちなみに, 空気の屈折率が 1.0 であり, 水は約 1.3 である。歯の屈折率は, 歯の性状と 部位によって少し異なるが, およそエナメル質は 1.6 であ り, 象牙質は 1.5 である。屈折率が異なると, その值に媒 体の光学的距離が変化し, 画面上での深さ方向が長くなる。 たとえば屈折率が 1.6 のエナメル質は, 縦方向が実際の 1.6 倍の長さに表示されるので, 注意しなければならない。

\section{今後の展望}

現在, 歯科臨床への応用に向けて開発が進められている SS-OCT は, 高解像度の画像を高速で取得できるため, 3D 画像を構築することもできる。3D 画像構築を利用した 検查は, $2 \mathrm{D}$ 画像よりも情報量において優れており, より
正確な診断を可能にすると思われる。また，新たな技術開 発によって OCT の画像精度と深度が高まれば, う蝕や龟 裂の診断のみならず, 歯周病や口腔粘膜疾患など, 他の疾 患の診断も可能になるかもしれない。今後の展開が期待さ れる。

\section{参考文献}

1) Huang D, Swanson EA, Lin CP, et al: Optical coherence tomography. Science, $254: 1178-1181,1991$.

2) Fujimoto J, Drexler W: Introduction to optical coherence tomography. In: Drexler W, Fujimoto JG (eds): Optical coherence tomography, Berlin Heidelberg, 2008, Springer, $1-45$.

3）角 保徳, 西田 功, 鄭 昌鎬, 他 : 光干渉断層画像診断法 の歯科臨床への応用口腔用 OCT 機器開発と歯牙齲蝕への 応用. 日歯医師会誌, $60: 1210-1222,2008$.

4) Shimada Y, Nakagawa H, Sadr A, et al: Noninvasive crosssectional imaging of proximal caries using swept-source optical coherence tomography (SS-OCT) in vivo. J Biophotonics, $7: 506-513,2014$.

5) Hariri I, Sadr A, Nakashima S, et al: Estimation of the enamel and dentin mineral content from the refractive index. Caries Res, 47 : 18-26, 2013.

6) Mandurah MM, Sadr A, Shimada Y, et al: Monitoring remineralization of enamel subsurface lesions by optical coherence tomography. J Biomed Opt, 18 : 046006, 2013.

7) Imai K, Shimada Y, Sadr A, et al: Noninvasive cross-sectional visualization of enamel cracks by optical coherence tomography. J Endod, 38 : 1269-1274, 2012.

8) Makishi P, Shimada Y, Sadr A, et al: Non-destructive 3D imaging of composite restorations using optical coherence tomography: marginal adaptation of self-etch adhesives. J Dent, 39 : 316-325, 2011.

9) Bakhsh TA, Sadr A, Shimada Y, et al: Non-invasive quantification of resin-dentin interfacial gaps using optical coherence tomography: validation against conforcal microscopy. Dent Mater, 27 : 915-925, 2011.

10) Ishibashi K, Ozawa N, Tagami J, et al: Swept-source optical coherence tomography as a new tool to evaluate defects of resin-based composite restorations. J Dent 39 : 543-548, 2011. 